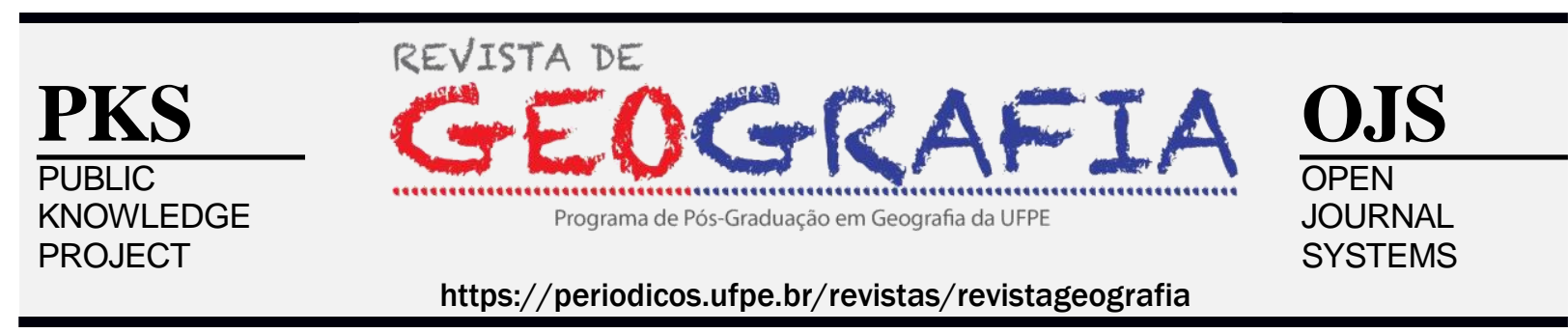

\title{
DESEMBOLSOS DO BNDES NO SETOR SUCROALCOOLEIRO NO NORDESTE BRASILEIRO
}

\author{
Ana Claudia Giannini Borges ${ }^{1}$, Lívia Martinez Brumatti ${ }^{2}$ \\ ${ }^{1}$ Professora do Departamento de Economia, Administração e Educação/Campus de Jaboticabal e da Pós- \\ Graduação em Geografia/Campus de Rio Claro - Universidade Estadual Paulista - UNESP. E-mail: \\ ana.giannini@unesp.br \\ ${ }^{2}$ Doutoranda em Controladoria e Contabilidade da Faculdade de Economia, Administração e Contabilidade - \\ Universidade de São Paulo-USP. E-mail: lmbrumatti@usp.br
}

Artigo recebido em 22/05/18 e aceito em 10/04/19

\begin{abstract}
RESUMO
Apesar da postura menos participativa do Estado nas relações de mercado, instituições financeiras públicas, como o BNDES, continuam sendo demandadas para investimento, inclusive para setores agrícolas, como o sucroalcooleiro. Nesse sentido, este trabalho busca identificar e analisar a atuação de credor do Estado, por meio do BNDES, para o setor sucroalcooleiro na região Nordeste, no período de 2001 a 2012. Para tal, foram levantados dados do BNDES, IBGE, MAPA e UNICA, os quais foram analisados a partir de uma abordagem descritiva. Constata-se que o BNDES teve papel importante na dinamização do setor sucroalcooleiro no período analisado, principalmente nas mesorregiões localizadas no extremo leste dos estados de Alagoas e Pernambuco. Apesar desta importância, foram identificadas algumas irregularidades no processo de desembolso, pois alguns municípios que não apresentam área plantada nem agroindústria, captaram recursos no BNDES, demonstrando a destinação inadequada dos recursos e a falta de fiscalização do Banco após o desembolso.
\end{abstract}

Palavras-chave: BNDES; Setor Sucroalcooleiro; Nordeste Brasileiro.

\section{BNDES DISBURSEMENTS ON SUGARCANE INDUSTRY IN BRAZILIAN NORTHEAST}

\begin{abstract}
Despite the less participatory attitude of the State in market relations, public financial institutions such as BNDES are still requested when organizations (from several different industries, including agricultural industries as sugarcane) demand investment. Thus, this work aims to identify and analyze the creditor role of the State through BNDES, in the face of Northeast sugarcane industry, from 2001 to 2012. To this end, we collected data from BNDES, IBGE, MAPA, and UNICA, and analyzed them through a descriptive approach. Our findings evidence BNDES has an important role in stimulating the sugarcane industry over the period, mainly in the meso-regions located at the Eastern end of the states of Alagoas and Pernambuco. Despite this importance, some irregularities were identified in the financing process, since some municipalities that do not have planted area or agroindustry have raised funds from BNDES, demonstrating the inadequate allocation of resources and the bank's lack of supervision after the disbursement.
\end{abstract}

Keywords: BNDES; Sugarcane Industry; Brazilian Northeast. 


\section{INTRODUÇÃO}

A postura do Estado, como promotor do desenvolvimento econômico, orientador do mercado e coordenador dos agentes econômicos, é modificada e reduzida no Brasil, a partir de fins da década de 1980 e início de 1990. Há, nesse período, um processo de ampliação da abertura comercial, com a liberalização da entrada de capital estrangeiro, o que promove o acirramento da concorrência no país (CARNEIRO, 2002). Isto resulta em um conjunto de mudanças econômicas, organizacionais, institucionais e produtivas que levam as empresas a se (re)organizar com o intuito de atingir seus objetivos.

Dentre essas mudanças, duas são destacadas: as alterações no mercado financeiro nacional e as dinâmicas dos setores produtivos, como no setor sucroalcooleiro. No Sistema Financeiro Nacional, há o processo de privatização e liquidação de bancos estatais e a liquidação e fusão e aquisição de bancos (BAER; NAZMI, 2002; STUDART, 2005). Essas mudanças, não resultaram na ampliação e na melhoria de crédito ofertado, como também não se observou o desenvolvimento efetivo do mercado de capitais primário. Por outro lado, verificam-se aplicações de longo prazo, a partir da criação de fundos de investimento e de pensão (STUDART, 2005).

Carvalho e Tepassê (2010) destacam que o mercado de capitais apresenta condições que dificultam o acesso de empresas de pequeno porte. Assim, as empresas 'excluídas' têm a alternativa de captar recursos via financiamento, para viabilizar seus investimentos, impactando negativamente o seu passivo. Ademais, o mercado de recursos de longo prazo no país apresenta elevado custo (taxa de juros e spread bancário ${ }^{1}$ ). O spread bancário total, entre março de 2011 a fevereiro de 2018, apresentou a mínima de 13,45\% em dezembro de 2013 e a máxima de 23,97\% em outubro de 2016 e para pessoa jurídica a mínima foi de 7,39\% em junho de 2013 e a máxima de 12,42\% em julho de 2016 (BCB, 2018). Com esta variação, o Banco Central do Brasil entende que o spread bancário merece atenção e que o diagnóstico se faz necessário para que se possa adotar medidas de longo prazo para reduzir o custo do crédito. (BCB, 2016).

Nesse contexto, há uma rediscussão sobre o papel dos bancos públicos no desenvolvimento econômico brasileiro, pois mesmo depois da reforma bancária, na década de 1990, “os prazos de financiamento bancário também continuaram muito curtos.". (STUDART, 2005, p. 350). Assim, de acordo com o autor, as instituições financeiras

\footnotetext{
${ }^{1}$ A definição de spread bancário, conforme BCB (2016, p. 11), "é a diferença, em pontos percentuais (p.p.), entre a taxa de juros pactuada nos empréstimos e financiamentos (taxa de aplicação) e a taxa de captação." Borges e Brumatti, $2019 \quad$ ISSN 0104-5490 111
} 
públicas, como o Banco Nacional de Desenvolvimento Econômico e Social (BNDES), voltam a ser "chamadas" para prover o mercado com crédito de longo prazo. Torres Filho e Costa (2012, p. 994-5), destacam que, no Brasil, esse crédito sempre foi exclusividade do BNDES e que $66 \%$ dos financiamentos de mais de cinco anos dos bancos brasileiros em 2009, incluindo tanto as operações com as empresas quanto com as famílias, eram realizados pelo banco de desenvolvimento. Do total, outros vinte pontos percentuais eram detidos por dois outros bancos públicos, Caixa Econômica Federal e Banco do Brasil, mas a maioria direcionada para crédito habitacional. Os autores ressaltam, também, que parte relevante desses créditos de instituições financeiras públicas é destinada para investimento para a produção.

Percebe-se, assim, que a atuação e a importância dos bancos públicos, principalmente federais permanecem. E como o BNDES é um ofertante de recursos de longo prazo, em moeda nacional, ele supre, de certa forma, a demanda interna das empresas e, portanto, minimiza essa falta do Sistema Financeiro Nacional.

O setor sucroalcooleiro, nesse contexto, também é impactado pelas mudanças observadas no país, com o início do processo de desregulamentação do setor, iniciada com a extinção do Instituto do Açúcar e do Álcool, em 1990 (BARROS; MOARES, 2002; BACCARIN, 2005). Observa-se, então, uma ampliação do poder de decisão do setor privado em detrimento do poder do Estado (BARROS; MOARES, 2002; VIAN, 2003; BACCARIN, 2005). Os processos de planejamento e organização interna e externa das agroindústrias ${ }^{2}$ se sujeitam à dinâmica de concorrência e competitividade dos mercados.

O setor sucroalcooleiro tem seu crescimento e relevância centrada em estados da região Centro-Sul do país, com destaque para São Paulo, devido às condições edafoclimáticas, infraestrutura e proximidade com o mercado consumidor. Além disso, considera-se a preferência por locais com outras unidades próximas, com o intuito de valer-se de sinergias produtivas, logísticas e outras (BORGES; COSTA, 2009).

Vian e Belik (2003, p. 154) apontavam que, no início do século XXI, o setor sucroalcooleiro "ainda não amadureceu o suficiente para assumir papéis que pudessem proporcionar a tão almejada autorregulação". Assim, Milanez, Barros e Faveret (2008) e Borges (2015) verificam que o Estado continua viabilizando a implantação de novas unidades, a ampliação e a modernização das unidades (por meio dos desembolsos do BNDES para o setor sucroalcooleiro), principalmente na região Centro-Sul (estados de São Paulo,

\footnotetext{
${ }^{2}$ Utiliza-se o termo agroindústria sucroalcooleira para as unidades que processam cana-de-açúcar e produzem etanol e/ou açúcar. 
Minas Gerais, Paraná, Goiás e Mato Grosso do Sul) do que na região Norte-Nordeste (Pernambuco e Alagoas). Delgado (2010) e Oliveira (2016) destacam que os setores produtores e exportadores de commodities $^{3}$, dentre eles o setor sucroalcooleiro, é favorecido por recursos públicos para sustentar o crescimento de suas atividades e a expansão no mercado mundial de commodities.

Assim, o desenvolvimento da atividade do setor continua sendo vinculado ao Estado $^{4}$, pelo estabelecimento de políticas e pela concessão de crédito. Nesse caso, tem-se o BNDES como agente financeiro, alocando recursos para as demandas do setor.

Mesmo considerando que o Estado/BNDES prioriza seus financiamentos para a região Centro-Sul, este trabalho tem como objetivo identificar e analisar a atuação de credor do BNDES para o setor sucroalcooleiro na região Nordeste. Isto porque, esta região é a originária do setor no Brasil, como destacam Duarte et al. (2009) ao definirem três rotas de expansão (década de 1940 há a migração do litoral nordestino para as áreas do sertão, na década de 1950 da região Nordeste para a Sudeste e, no século XXI, para a região CentroOeste do país). Além disso, pode-se afirmar que o setor sucroalcooleiro ainda se faz presente e relevante no Nordeste, pois a área plantada de cana-de-açúcar para a indústria está entre as quatro maiores da região, no século XXI (IBGE, 2017).

A análise será realizada para o período de 2001 a 2012, considerando primeiramente por Unidade Federativa (UF): (i) a evolução dos desembolsos; (ii) e as finalidades dos desembolsos do BNDES. Após são apresentadas informações dos desembolsos, da área plantada, da quantidade de cana-de-açúcar moída e do número de agroindústrias por mesorregião ${ }^{5}$, apontando a concentração dessa cultura em áreas específicas do Nordeste.

\section{MÉTODOS}

Este artigo é a ampliação de estudos realizados a partir do projeto financiado pela Fundação de Amparo à Pesquisa do Estado de São Paulo (FAPESP), denominado "Estado e desenvolvimento: análise dos programas de financiamento do BNDES para o Setor

\footnotetext{
${ }^{3}$ As commodities listadas nas negociações da BM\&F são boi gordo, café arábica, milho, soja, ouro, petróleo, açúcar cristal, etanol anidro e etanol hidratado, sendo os três últimos produtos do setor sucroalcooleiro (BM\&F, 2019).

${ }^{4}$ A intervenção do Estado, ao longo da história do setor, sempre existiu, embora com intensidade e objetivos diferentes, apresentando, inclusive, descontinuidades (BARROS; MORAES, 2002; VIAN, 2003).

${ }^{5}$ Segundo IBGE (1990, p. 8, grifo do autor), a mesorregião é formada por municípios contíguos que apresentam as seguintes dimensões: "o processo social, como determinante, o quadro natural, como condicionante, e a rede de comunicação e de lugares, como elemento de articulação espacial. Essas três dimensões possibilitam que o espaço delimitado como mesorregião tenha uma identidade regional. Esta identidade é uma realidade construída ao longo do tempo pela sociedade que aí se formou."

\begin{tabular}{lll}
\hline Borges e Brumatti, 2019 & 113
\end{tabular}
} 
Sucroalcooleiro (2001-2008)". Nesse projeto, considerava-se a região Centro-Oeste, Sudeste e Sul, no período de 2001 a 2008, e neste artigo objetiva-se analisar a região Nordeste, no período de 2001 a 2012.

A seleção da região Nordeste se deu por duas razões: pela importância prática da produção canavieira na região, visto que a cana-de-açúcar ainda é uma cultura relevante nesse território (Duarte et al., 2009); e pela contribuição do contexto que permite evidenciar que, mesmo em uma região com produção menor (quando comparada às demais regiões do país), o Estado, por meio de suas instituições financeiras, continua a ser necessário na promoção do setor produtivo. E esta evidência levanta questionamentos sobre a efetividade das práticas de autorregulação do mercado.

Para a realização das análises, foram feitas coletas de informações e de dados no BNDES, no Ministério da Agricultura Pecuária e Abastecimento (MAPA), na base de dados no Sistema IBGE de Recuperação Automática - SIDRA - do IBGE e na União da Indústria de Cana-de-açúcar (UNICA).

Os dados do BNDES foram disponibilizados em dois momentos distintos, mediante solicitação no ano de 2010 e de 2013. Os dados apresentam as finalidades dos desembolsos, por unidade federativa (UF) e por grandes regiões, mas a forma de agregar e disponibilizar esses dados, pelo BNDES, é modificado do período de 2001 a 2008 para o de 2009 a 2012 , por isso, esses dados estão apresentados no artigo como BNDES (2010) e BNDES (2013). A análise por município e mesorregião somente pode ser realizada por volume de desembolsos, sem especificação das finalidades, compreendendo o período de 2004 a 2012. Os valores monetários foram atualizados pelo Índice Geral de Preço - Disponibilidade Interna (IGPDI/FGV), ano base 2017.

Para a análise dos dados é considerada também a quantidade de área plantada em hectares de cana-de-açúcar (2000 e 2012), por mesorregião e unidade federativa, a partir da base de dados do SIDRA (IBGE, 2017). O número de agroindústrias sucroalcooleiras na região Nordeste, por unidade federativa, é obtido nos cadastros de agroindústrias do MAPA para vários anos, de 2008 a 2012. Além disto, utiliza-se, também, a quantidade de cana-deaçúcar moída na safra de 2000/2001 e 2011/2012, dados obtidos na UNICA (2017).

Para analisar a relação dos desembolsos do BNDES com a área plantada e a quantidade de cana-de-açúcar moída foi realizada uma caracterização da região Nordeste, apontando: (i) a participação da cana-de-açúcar na área territorial total da região (indicando as principais culturas desenvolvidas nesse território); (ii) a relevância do setor sucroalcooleiro na 
região analisada, considerando a área plantada frente a área do território; e (ii) o nível de diversidade da produção na região Nordeste (Índice de Theil - Tabela 1). De acordo com a metodologia de Theil, quanto mais próximo o valor estiver de zero maior a concentração (monopolização) de culturas em determinado território. Ao mesmo tempo, quanto mais distante de zero, maior a diversidade.

Tabela 1. Classificação do Índice de diversidade produtiva (Theil)

\begin{tabular}{cl}
\hline Índice de Theil (H) & \multicolumn{1}{c}{ Classificação das atividades } \\
\hline $\mathrm{H}=0,000$ & Concentração máxima (Monopolização) \\
Quanto maior for o H de 0,000 & Maior a Diversidade
\end{tabular}

Fonte: Elaborada a partir de Souza (2008) e Souza e Cabero Diegues (2012).

De maneira geral, esta pesquisa tem um caráter descritivo, embora ofereça também uma análise crítica sobre os desembolsos na região analisada.

\section{DESEMBOLSOS DO BNDES}

Os desembolsos realizados pelo BNDES no setor Sucroalcooleiro, de 2001 a 2012, somam o montante de $\mathrm{R} \$ 63,63$ bilhões, distribuídos em 26 das 27 unidades federativas visto que Roraima não recebeu recurso no período. Esse montante está dividido da seguinte forma: R \$ 57,02 bilhões são desembolsos para a região Centro-Sul, o que representa 89,61\% do total; $\mathrm{R} \$ 4,92$ bilhões para desembolsos interestaduais (7,73\%), quando o demandante faz a captação e o recurso é utilizado em diferentes unidades federativas; e $\mathrm{R} \$ 1,69$ bilhões para a região Norte-Nordeste, que participa com 2,66\% do total (BNDES 2010 e 2013). Salienta-se que a região Nordeste captou 2,5\% (R \$ 1,59 bilhões) do total Brasil. Esse montante é inferior ao observado nos desembolsos interestaduais. É importante considerar que a região Nordeste apresenta solo e temperatura que podem favorecer a cultura canavieira, no entanto a topografia e o fator hídrico são desfavoráveis a esta cultura (CONAB, 2016).

Os principais anos de captação da região Nordeste são os de 2002, 2010 e 2011, somando 49\% ( $\mathrm{R} \$ 780,85$ milhões) dos desembolsos para esta região, e as cinco unidades federativas com maior captação de recursos do BNDES (FIGURA 1), na região Nordeste, são: Alagoas (42,65\%), Pernambuco (23,87\%), Rio Grande do Norte (13,10\%), Paraíba $(9,34 \%)$ e Piauí (3,73\%). Juntas somam R \$ 1,48 bilhões, o que representa 92,68\% do captado na região Nordeste. Vale ressaltar que os estados de Alagoas e Pernambuco, em 2001, já detinham 74,29\% da área plantada de cana-de-açúcar da região Nordeste (IBGE, 2017).

Os valores dos maiores desembolsos são para: Alagoas em 2002 (R\$ 215,79 milhões); Rio Grande do Norte em 2011 (R \$ 112,02 milhões); Alagoas em 2010 (R \$ 111,33 
milhões); Alagoas em 2011 (R \$ 83,85 milhões); Pernambuco em 2007 (R \$ 69,21 milhões); Alagoas em 2003 (R \$ 65,23 milhões); e Pernambuco em 2005 (R \$ 45,52 milhões). Esses desembolsos representam $44,11 \%$ dos recursos recebido pela região Nordeste no período. Vale ressaltar que, além desses destaques, Alagoas recebe em outros três anos recursos acima de R\$ 30 milhões, Pernambuco em outros quatro anos e Rio Grande do Norte em mais um ano.

Figura 1 - Total de desembolsos do BNDES para o setor sucroalcooleiro, por unidade federativa do Nordeste, no período de 2001 a 2012.

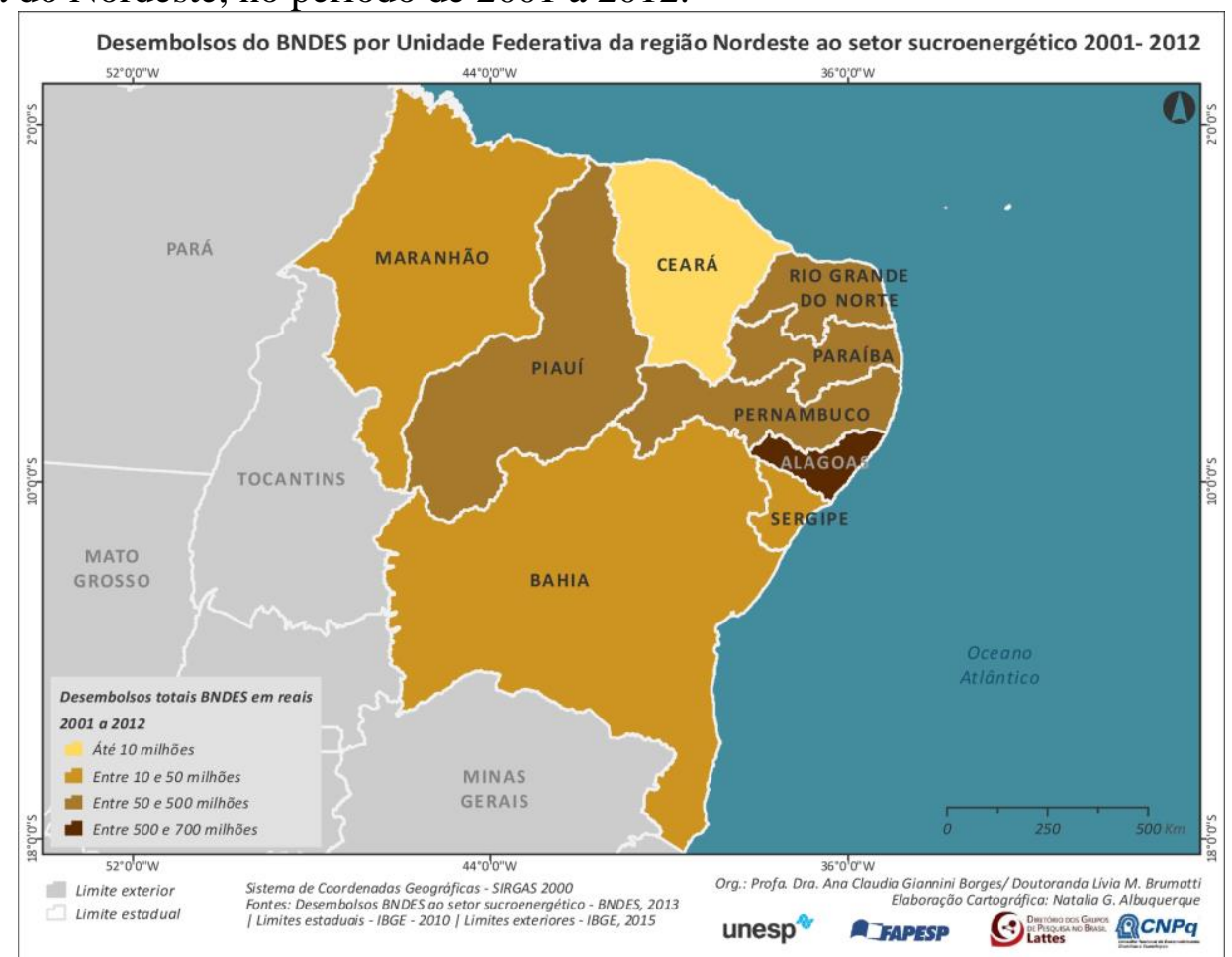

Fonte: Elaborada a partir de dados obtidos no BNDES nos anos de 2010 e 2013, mediante solicitação.

Os recursos do BNDES são destinados para diferentes finalidades, Tabela 2 e 3. No período de 2001 a 2008, para as unidades federativas da Região Nordeste, identificam-se 10 finalidades de desembolso: capital de giro; capitalização institucional; cartão BNDES; desenvolvimento tecnológico; expansão; financiamento de compra; implantação; pósembarque; pré-embarque; racionalização (TABELA 2).

As finalidades que apresentam o maior volume de recurso são 'financiamento de compra de máquinas e serviços' e 'expansão', respectivamente, somando R \$ 490,36 milhões e R \$ 345,79 milhões e que representam $88,81 \%$ do total dos desembolsos para o Nordeste. Para Norte-Nordeste, do total dos recursos captados, estas duas finalidades representam $85,87 \%$ ( $\mathrm{R} \$ 858,72$ milhões). 
Os maiores desembolsos por finalidade ocorrem nas seguintes unidades federativas: Alagoas com R \$ 187,87 milhões para 'financiamento de compra de máquinas e serviços' e R \$ 172,47 milhões para 'expansão'; e Pernambuco com R\$ 215,47 milhões para 'financiamento de compra de máquinas e serviços’ e R \$ 54,48 milhões para 'expansão'. Vale destacar que os desembolsos para as finalidades de pré e pós-embarque, 'racionalização' e 'desenvolvimento tecnológico’ são destinados, respectivamente, para Paraíba (R \$ 6,71 milhões), Alagoas (R\$ 63,56 milhões), Pernambuco ( $\mathrm{R}$ 5,33 milhões) e Ceará ( $\mathrm{R}$ 2,28 milhões).

Tabela 2 - Desembolsos do BNDES para o setor sucroalcooleiro, por finalidade, para unidade federativa do Nordeste, no período de 2001 a 2008.

\begin{tabular}{|c|c|c|c|c|}
\hline $\begin{array}{c}\text { Unidades Federativas/ } \\
\text { Região/ País } \\
\end{array}$ & Capital De Giro & $\begin{array}{c}\text { Capitalização Institu- } \\
\text { cional Financieira }\end{array}$ & Cartão Bndes & $\begin{array}{c}\text { Desenvolvimento } \\
\text { Tecnológico } \\
\end{array}$ \\
\hline Alagoas & $\overline{0}$ & 0 & 0 & 0 \\
\hline Bahia & 0 & 107.459 & 18.475 & 0 \\
\hline Ceará & 0 & 0 & 0 & 2.282 .593 \\
\hline Maranhão & 0 & 0 & 0 & 0 \\
\hline Paraíba & 15.303 .949 & 35.820 & 125.925 & 0 \\
\hline Pernambuco & 0 & 0 & 0 & 0 \\
\hline Piauí & 0 & 0 & 0 & 0 \\
\hline Rio Grande do Norte & 3.980 .434 & 0 & 0 & 0 \\
\hline Sergipe & 0 & 0 & 0 & 0 \\
\hline Nordeste & 19.284 .383 & 143.278 & 144.400 & 2.282 .593 \\
\hline Norte-Nordeste & 19.284 .383 & 321.757 & 144.400 & 2.282 .593 \\
\hline Brasil & 229.666 .015 & $\mathbf{5 3 . 8 3 8 . 8 7 8}$ & 1.369 .306 & 2.282 .593 \\
\hline $\begin{array}{c}\text { Unidades Federativas/ } \\
\text { Região/ País }\end{array}$ & Expansão & $\begin{array}{c}\text { Financiamento } \\
\text { Compra Máq./Serv. }\end{array}$ & Implantação & $\begin{array}{l}\text { Pós-Embarque } \\
\text { Suppliers }\end{array}$ \\
\hline Alagoas & 172.467 .922 & 187.870 .866 & 0 & 63.555 .236 \\
\hline Bahia & 0 & 15.251 .410 & 62.475 & 0 \\
\hline Ceará & 0 & 236.882 & 0 & 0 \\
\hline Maranhão & 5.685 .983 & 9.987 .450 & 3.076 .603 & 0 \\
\hline Paraíba & 43.000 .895 & 24.993 .291 & 0 & 0 \\
\hline Pernambuco & 54.475 .097 & 215.470 .630 & 4.298 .647 & 0 \\
\hline Piauí & 31.436 .776 & 17.909 .808 & 0 & 0 \\
\hline Rio Grande do Norte & 38.725 .709 & 17.898 .249 & 417.643 & 0 \\
\hline Sergipe & 0 & 737.187 & 0 & 0 \\
\hline Nordeste & 345.792 .380 & 490.355 .772 & 7.855 .368 & 63.555 .236 \\
\hline Norte-Nordeste & 352.196 .313 & 516.035 .668 & 7.855 .368 & 63.555 .236 \\
\hline Brasil & 7.456 .122 .762 & 10.710 .135 .845 & 8.251.915.418 & 232.994.089 \\
\hline $\begin{array}{c}\text { Unidades Federativas/ } \\
\text { Região/ País }\end{array}$ & $\begin{array}{c}\text { Pré-Embarque } \\
\text { Exportação }\end{array}$ & Racionalização & \begin{tabular}{|c|} 
Outras \\
Finalidades \\
\end{tabular} & Total \\
\hline Alagoas & 0 & 0 & 0 & 423.894 .025 \\
\hline Bahia & 0 & 0 & 0 & 15.439 .819 \\
\hline Ceará & 0 & 0 & 0 & 2.519 .475 \\
\hline Maranhão & 0 & 0 & 0 & 18.750 .036 \\
\hline Paraíba & 6.708 .105 & 0 & 0 & 90.167 .983 \\
\hline Pernambuco & 0 & 5.330 .304 & 0 & 279.574 .678 \\
\hline Piauí & 0 & 0 & 0 & 49.346 .584 \\
\hline Rio Grande do Norte & 0 & 0 & 0 & 61.022 .034 \\
\hline Sergipe & 0 & 0 & 0 & 737.187 \\
\hline Nordeste & 6.708 .105 & 5.330 .304 & 0 & 941.451 .820 \\
\hline Norte-Nordeste & 6.708 .105 & 5.330 .304 & 0 & 973.714 .127 \\
\hline Brasil & 39.376 .790 & 239.245.528 & 1.272 .043 .893 & 28.488.991.119 \\
\hline
\end{tabular}

Fonte: Elaborada a partir de dados obtidos no BNDES no ano de 2010, mediante solicitação. 
Na Tabela 3, têm-se os desembolsos por destino no período de 2009 a 2012, por região e unidade da federação e, nesse caso, observa-se que as finalidades disponibilizadas pelo BNDES diferem das apresentadas na Tabela 2. Os destinos são por atividades e produtos gerados, compondo seis tipos (comércio atacadista de açúcar, cultivo de cana-de-açúcar, geração de energia elétrica, fabricação de açúcar refinado, fabricação de etanol e fabricação de açúcar bruto).

Para esse caso, a região Nordeste recebe $90,76 \%$ e a região Norte 9,24\% dos desembolsos totais da região Norte-Nordeste, sendo as principais unidades federativas captadoras: Alagoas com 35,59\% (R \$ 255,73 milhões); Rio Grande do Norte com 20,56\% (R\$ 147,72 milhões); Pernambuco com 14,02\% (R \$ 100,74 milhões); e Paraíba com 8,16\% ( $\mathrm{R} \$ 58,62$ milhões) da região Norte-Nordeste.

Tabela 3 - Desembolsos do BNDES para o setor sucroalcooleiro, por finalidade, para unidade federativa do Nordeste, no período de 2009 a 2012.

\begin{tabular}{|c|c|c|c|c|}
\hline $\begin{array}{c}\text { Unidades Federativas/ } \\
\text { Região/País }\end{array}$ & $\begin{array}{c}\text { Comércio Atacadista } \\
\text { De Açúcar }\end{array}$ & $\begin{array}{l}\text { Cultivo De Cana- } \\
\text { De-Açúcar }\end{array}$ & $\begin{array}{c}\text { Ge ração De Energia } \\
\text { Elétrica (Co-Geração) } \\
\text { Cana-De-Açúcar }\end{array}$ & \\
\hline Alagoas & 29.051 .131 & 68.524 .372 & 0 & \\
\hline Bahia & 1.286 .515 & 4.243 .434 & 0 & \\
\hline Ceará & 667.248 & 3.097 .532 & 0 & \\
\hline Maranhão & 496.530 & 952.703 & 0 & \\
\hline Paraíba & 1.892 .086 & 12.417 .705 & 0 & \\
\hline Pernambuco & 76.535 & 16.870 .402 & 0 & \\
\hline Piauí & 0 & 3.888 .428 & 0 & \\
\hline Rio Grande do Norte & 664.980 & 11.759 .113 & 133.584 .066 & \\
\hline Sergipe & 0 & 9.989 .835 & 0 & \\
\hline Nordeste & 34.135 .025 & 131.743 .522 & 133.584 .082 & \\
\hline Norte-Nordeste & 36.862 .314 & 138.165 .032 & 133.584 .082 & \\
\hline Brasil & 338.893.353 & 5.344.204.906 & 3.917.530.281 & \\
\hline $\begin{array}{c}\text { Unidades Federativas/ } \\
\text { Região/País }\end{array}$ & $\begin{array}{c}\text { Fabricação De } \\
\text { Açúcar Refinado }\end{array}$ & $\begin{array}{c}\text { Fabricação De } \\
\text { Etanol }\end{array}$ & $\begin{array}{c}\text { Fabricação De Açúcar } \\
\text { Bruto }\end{array}$ & Total \\
\hline Alagoas & 0 & 0 & 158.150 .427 & 255.725 .930 \\
\hline Bahia & 2.194 .292 & 301.025 & 21.916 .825 & 29.942 .090 \\
\hline Ceará & 0 & 150.219 & 144.166 & 4.059 .165 \\
\hline Maranhão & 299.379 & 14.680 .655 & 0 & 16.429 .267 \\
\hline Paraíba & 265.401 & 7.310 .040 & 36.730 .300 & 58.615 .532 \\
\hline Pernambuco & 1.244 .962 & 8.241 .651 & 74.301 .679 & 100.735 .230 \\
\hline Piauí & 0 & 6.222 .303 & 0 & 10.110 .731 \\
\hline Rio Grande do Norte & 0 & 0 & 1.715 .530 & 147.723 .688 \\
\hline Sergipe & 0 & 13.461 .940 & 5.293 .433 & 28.745 .207 \\
\hline Nordeste & 4.004 .034 & 50.367 .828 & 298.252 .350 & 652.086 .841 \\
\hline Norte-Nordeste & 6.311 .649 & 105.276 .071 & 298.252 .350 & 718.451 .495 \\
\hline Brasil & 145.522 .761 & 16.476.393.526 & 8.919.394.038 & 35.141 .938 .864 \\
\hline
\end{tabular}

Fonte: Elaborada a partir de dados obtidos no BNDES no ano de 2013, mediante solicitação.

Os principais destinos, na região Nordeste, são a 'fabricação de açúcar bruto' (R\$ 298,25 milhões), a 'geração de energia elétrica' a partir da 'cogeração de cana-de-açúcar' (R\$ 133,58 milhões) e o ‘cultivo de cana-de-açúcar' (R\$ 131,74 milhões). As unidades federativas com maior destaque, nesse período, são: Alagoas para 'fabricação de açúcar bruto', com R\$ 
158,15 milhões e para 'cultivo de cana-de-açúcar', com R \$ 68,52 milhões; Rio Grande do Norte para a 'geração de energia elétrica' a partir da cogeração de cana-de-açúcar, com R \$ 133,58 milhões; e Pernambuco, com mais de 74 milhões destinados para 'fabricação de açúcar bruto'. É importante destacar que, segundo CONAB (2013), os estados de Alagoas, Pernambuco e Rio Grande do Norte têm tradição na produção de açúcar, o que ajuda a justificar o fato dos dois primeiros estados terem arrecadado o maior volume de recurso para a fabricação de açúcar bruto, o equivalente a 77,93\% da região Nordeste para esse destino.

Ao analisar os desembolsos do BNDES e a variação da área plantada e de cana-deaçúcar moída (TABELA 4), observa-se que duas das unidades federativas com maiores desembolsos (Alagoas e Pernambuco) tiveram variação da área plantada negativa e pouca variação de cana-de-açúcar moída. Ao mesmo tempo, estas unidades federativas são as que concentram maior área plantada e quantidade de moagem de cana-de-açúcar da região Nordeste. A redução na área plantada e relativo aumento na quantidade de cana moída pode indicar certo aumento em produtividade nesses dois estados, que pode estar atrelado, dentre outros, ao aumento de crédito para máquinas e equipamentos no mesmo período.

Tabela 4. Desembolsos do BNDES (R\$), área plantada (ha) e quantidade de moagem (ton.) de cana-de-açúcar, por Unidade Federativa, no período de 2000 a 2012.

\begin{tabular}{|c|c|c|c|c|c|c|c|}
\hline \multirow{2}{*}{ Unidade Federativa } & \multicolumn{2}{|c|}{ Área plantada (Hectares) } & \multirow{2}{*}{$\begin{array}{c}\text { Variação } \\
(\%)\end{array}$} & \multicolumn{2}{|c|}{ Cana-de-açúcar moída } & \multirow{2}{*}{$\begin{array}{c}\text { Variação } \\
(\%)\end{array}$} & \multirow{2}{*}{$\begin{array}{c}\text { Desembolsos } \\
(\mathbf{R} \$)^{*}\end{array}$} \\
\hline & 2000 & 2012 & & $2000 / 2001$ & $2011 / 2012$ & & \\
\hline Alagoas & 461.912 & 433.300 & $-6,19$ & 24.394 & 27.705 & 13,58 & 679.619 .955 \\
\hline Bahia & 92.060 & 118.033 & 28,21 & 1.921 & 2.557 & 33,15 & 45.381 .909 \\
\hline Ceará & 34.535 & 40.248 & 16,54 & 66 & 120 & 82,57 & 6.578 .641 \\
\hline Maranhão & 19.912 & 49.534 & 148,76 & 799 & 2.266 & 183,38 & 35.179 .303 \\
\hline Paraíba & 93.055 & 125.985 & 35,39 & 3.594 & 6.723 & 87,05 & 148.783 .515 \\
\hline Pernambuco & 359.662 & 309.928 & $-13,83$ & 14.367 & 17.642 & 22,80 & 380.309 .908 \\
\hline Piauí & 7.241 & 15.629 & 115,84 & 248 & 992 & 299,51 & $\begin{array}{r}59.457 .315 \\
\end{array}$ \\
\hline Rio Grande do Norte & 43.380 & 71.300 & 64,36 & 2.388 & 2.973 & 24,50 & 208.745 .722 \\
\hline Sergipe & 21.208 & 53.158 & 150,65 & 1.414 & 2.548 & 80,25 & 29.482 .394 \\
\hline Região Nordeste & 1.132 .965 & 1.217 .115 & 7,43 & 49.191 & 63.527 & 29,14 & 1.593.538.661 \\
\hline
\end{tabular}

*Período de 2001 a 2012.

Fonte: Elaborada a partir de dados obtidos no BNDES nos anos de 2010 e 2013, mediante solicitação, IBGE (2017) e UNICA (2017).

Observa-se que os desembolsos do BNDES estão atrelados à magnitude do setor para as unidades federativas de Alagoas e Pernambuco. Para as demais unidades federativas, o BNDES coloca-se como um colaborador para a expansão da área plantada e moagem de canade-açúcar, o que vai de encontro com os apontamentos de Delgado (2010) e Oliveira (2016) ao destacarem a importância do Estado para o crescimento dos setores produtores e exportadores de commodities, que nesse caso se viabiliza pelo BNDES. Além disso, é 
importante destacar que esse crescimento tende a impactar na paisagem e na lógica de produção, como verificado por SOUZA (2008) e Borges (2015).

Porém, é importante ressaltar que os recursos para investimento também podem ter outras origens, tais como próprios, de bancos privados, abertura de capital das empresas e de outras instituições financeiras públicas.

\section{DESEMBOLSO TOTAL POR MESORREGIÃO}

Ao analisar os dados das mesorregiões das unidades federativas da região Nordeste, é possível identificar aquelas que concentram o cultivo da cana-de-açúcar, de 2004 a 2012 (TABELA 5), e possuem agroindústrias sucroalcooleiras, em 2012 (FIGURA 2).

As mesorregiões situadas na costa leste dos estados de Rio Grande do Norte (Leste Potiguar), Paraíba (Mata Paraibana), Pernambuco (Metropolitana de Recife e Mata Pernambucana) e Alagoas (Leste Alagoano) são as que concentram as maiores áreas de produção de cana-de-açúcar no Nordeste. Além destas, há a mesorregião do Sul Baiano e os municípios de Juazeiro na Bahia e de São Raimundo das Mangabeiras no Maranhão, no ano de 2012.

Dessas mesorregiões destacadas, do total do Nordeste, o Leste Alagoano e a Mata Pernambucana são as que apresentam a maior participação de área plantada, tanto em 2004 com 410,5 mil ha $(36,23 \%)$ e 268 mil ha (23,70\%) - como em 2012 - com 420 mil ha $(34,53 \%)$ e $232 \mathrm{mil}$ ha $(19,09 \%)$ - respectivamente. Estas, juntamente com as mesorregiões Metropolitana do Recife, Mata Paraibana e Leste Potiguar, são as que apresentam a maior área de cana-de-açúcar frente as suas áreas de território.

Por outro lado, as mesorregiões de Borborema na Paraíba e Sertão Sergipano em Sergipe e Central Potiguar no Rio Grande do Norte não apresentam área plantada de cana-deaçúcar em 2000, sendo que as duas primeiras também não têm cultivo em 2012. Além disso, 14 das 42 mesorregiões de todos os estados, da região Nordeste, apresentam quantidade de área plantada inferior a 1.000 hectares em 2000 e apenas a mesorregião do Sertão Pernambucano passa a ter área plantada superior a 1.000 hectares em 2012, porém ainda com área reduzida (1.124 hectares). 
Tabela 5 - Área Plantada de cana-de-açúcar em hectares e participação na área territorial (\%), por mesorregião e estado, em 2004 e 2012.

\begin{tabular}{|c|c|c|c|c|c|c|}
\hline \multirow{2}{*}{$\begin{array}{l}\text { Mesorregião/Unidade } \\
\text { Federativa }\end{array}$} & \multirow{2}{*}{$\begin{array}{c}\text { Área } \\
\text { Territorial } \\
\text { hectares } \\
\text { (a) } \\
\end{array}$} & \multicolumn{3}{|c|}{$\begin{array}{c}\text { Área Plantada de cana-de- } \\
\text { açúcar (hectares) }\end{array}$} & \multicolumn{2}{|c|}{$\begin{array}{c}\text { Participação } \\
(\%)\end{array}$} \\
\hline & & \begin{tabular}{|c|}
2004 \\
(b)
\end{tabular} & \begin{tabular}{c|}
2012 \\
(c) \\
\end{tabular} & \begin{tabular}{|c|} 
Variação \\
$(\%)$
\end{tabular} & $(\mathbf{b} / \mathbf{a})$ & (c/a) \\
\hline Agreste Alagoano & 576.980 & 12.645 & 12.993 & 2,75 & 2,19 & 2,25 \\
\hline Leste Alagoano & 1.324 .070 & 410.515 & 420.219 & 2,36 & 31,00 & 31,74 \\
\hline Sertão Alagoano & 876.880 & 65 & 88 & 35,38 & 0,01 & 0,01 \\
\hline Alagoas & 2.777 .930 & 461.912 & 433.300 & $-6,19$ & 16,63 & 15,60 \\
\hline Centro Norte Baiano & 8.217 .820 & 1.794 & 1.361 & $-24,14$ & 0,02 & 0,02 \\
\hline Centro Sul Baiano & 12.787 .830 & 17.607 & 16.445 & $-6,60$ & 0,14 & 0,13 \\
\hline Extremo Oeste Baiano & 11.667 .740 & 10.819 & 10.517 & $-2,79$ & 0,09 & 0,09 \\
\hline Metropolitana de Salvador & 1.128 .270 & 13.600 & 17.651 & 29,79 & 1,21 & 1,56 \\
\hline Nordeste Baiano & 5.645 .530 & 196 & 93 & $-52,55$ & 0,00 & 0,00 \\
\hline Sul Baiano & 5.472 .300 & 24.820 & 54.486 & 119,52 & 0,45 & 1,00 \\
\hline Vale São-Franciscano da Bahia & 11.563 .610 & 18.110 & 17.480 & $-3,48$ & 0,16 & 0,15 \\
\hline Bahia & 56.483 .090 & 92.060 & 118.033 & 28,21 & 0,16 & 0,21 \\
\hline Centro-Sul Cearense & 995.570 & 451 & 294 & $-34,81$ & 0,05 & 0,03 \\
\hline Jaguaribe & 1.844 .120 & 103 & 1.978 & 1820,39 & 0,01 & 0,11 \\
\hline Metropolitana de Fortaleza & 376.750 & 2.835 & 2.256 & $-20,42$ & 0,75 & 0,60 \\
\hline Noroeste Cearense & 3.450 .450 & 11.539 & 19.051 & 65,10 & 0,33 & 0,55 \\
\hline Norte Cearense & 2.107 .380 & 12.404 & 13.822 & 11,43 & 0,59 & 0,66 \\
\hline Sertões Cearenses & 4.628 .570 & 675 & 641 & $-5,04$ & 0,01 & 0,01 \\
\hline Sul Cearense & 1.489 .200 & 5.965 & 2.206 & $-63,02$ & 0,40 & 0,15 \\
\hline Ceará & 14.892 .050 & 34.535 & 40.248 & 16,54 & 0,23 & 0,27 \\
\hline Centro Maranhense & 5.464 .970 & 1.011 & 1.710 & 69,14 & 0,02 & 0,03 \\
\hline Leste Maranhense & 7.053 .460 & 5.847 & 21.163 & 261,95 & 0,08 & 0,30 \\
\hline Norte Maranhense & 5.269 .170 & 242 & 401 & 65,70 & 0,00 & 0,01 \\
\hline Oeste Maranhense & 8.655 .000 & 1.522 & 591 & $-61,17$ & 0,02 & 0,01 \\
\hline Sul Maranhense & 6.750 .950 & 18.169 & 25.669 & 41,28 & 0,27 & 0,38 \\
\hline Maranhão & 33.193 .550 & 19.912 & 49.534 & 148,76 & 0,06 & 0,15 \\
\hline Agreste Paraibano & 1.293 .100 & 4.753 & 6.171 & 29,83 & 0,37 & 0,48 \\
\hline Borborema & 1.557 .660 & - & - & - & - & - \\
\hline Mata Paraibana & 523.270 & 110.942 & 119.290 & 7,52 & 21,20 & 22,80 \\
\hline Sertão Paraib & 2.272 .920 & 976 & 524 & $-46,31$ & 0,04 & 0,02 \\
\hline Paraíba & 5.646 .950 & 93.055 & 125.985 & 35,39 & 1,65 & 2,23 \\
\hline Agreste Pernambucano & 2.448 .000 & 9.277 & 28.873 & 211,23 & 0,38 & 1,18 \\
\hline Mata Pernambucana & 839.530 & 268.466 & 232.459 & $-13,41$ & 31,98 & 27,69 \\
\hline Metropolitana de Recife & 279.080 & 84.687 & 47.300 & $-44,15$ & 30,35 & 16,95 \\
\hline São Francisco Pernambucano & 2.448 .290 & 45 & 172 & 282,22 & 0,00 & 0,01 \\
\hline Sertão Pernambucano & 3.799 .740 & 1.079 & 1.124 & 4,17 & 0,03 & 0,03 \\
\hline Pernambuco & 9.814 .630 & 359.662 & 309.928 & $-13,83$ & 3,66 & 3,16 \\
\hline Centro-Norte Piauiense & 5.525 .420 & 7.216 & 13.445 & 86,32 & 0,13 & 0,24 \\
\hline Norte Piauiense & 2.215 .220 & 891 & 940 & 5,50 & 0,04 & 0,04 \\
\hline Sudeste Piauiense & 4.616 .270 & 224 & 260 & 16,07 & 0,00 & 0,01 \\
\hline Sudoeste Piauiense & 12.800 .750 & 681 & 984 & 44,49 & 0,01 & 0,01 \\
\hline Piauí & 25.157 .660 & 7.241 & 15.629 & 115,84 & 0,03 & 0,06 \\
\hline Agreste Potiguar & 938.540 & 3.489 & 7.164 & 105,33 & 0,37 & 0,76 \\
\hline Central Potiguar & 1.581 .030 & 10 & 57 & 470,00 & 0,001 & 0,004 \\
\hline Leste Potiguar & 644.030 & 48.359 & 63.860 & 32,05 & 7,51 & 9,92 \\
\hline Oeste Potiguar & 2.117 .470 & 475 & 219 & $-53,89$ & 0,02 & 0,01 \\
\hline Rio Grande do Norte & 5.281 .070 & 43.380 & 71.300 & 64,36 & 0,82 & 1,35 \\
\hline Agreste Sergipano & 590.280 & 1.654 & 4.633 & 180,11 & 0,28 & 0,78 \\
\hline Leste Sergipano & 870.000 & 23.548 & 48.525 & 106,07 & 2,71 & 5,58 \\
\hline Sertão Sergipano & 731.550 & & - & - & - & \\
\hline Sergipe & 2.191 .840 & 21.208 & 53.158 & 150,65 & 0,97 & 2,43 \\
\hline
\end{tabular}

Nota: Área territorial abrange a área urbana e a área com lavoura, pastagem e mata.

Fonte: IBGE (2017). 
Embora haja congruência entre a localização das agroindústrias comparada às áreas plantadas de cana-de-açúcar, ao analisar os dados dos desembolsos do BNDES para o setor no período de 2004 a 2012 (FIGURA 2), verifica-se que existem municípios que não apresentam produção de cana-de-açúcar de 2001 a 2012, nem agroindústrias sucroalcooleiras de 2008 a $2012^{6}$, no entanto recebem recursos do BNDES.

Entre esses casos, pode-se citar: Brumado ( $\mathrm{R} \$$ 38.071), Irecê ( $\mathrm{R} \$$ 34.936) e Jussara ( $\mathrm{R}$ \$ 442.535) na Bahia; Sobral ( $\mathrm{R}$ \$ 152.311) e São Luís do Curu (R \$ 83.275) no Ceará; Açailândia ( $\mathrm{R}$ \$ 266.431), Lago da Pedra ( $\mathrm{R}$ \$ 81.556) e Santa Inês no Maranhão ( $\mathrm{R}$ \$ 414.973); Campina Grande ( $\mathrm{R}$ \$ 39.806), Gurinhém ( $\mathrm{R} \$$ 177.621) e Prata ( $\mathrm{R} \$ 17.910)$ na Paraíba; Campo Maior (R\$ 245.745) no Piauí; Aquidabã no Sergipe (R\$ 168.105).

Figura 2 - Área plantada e agroindústrias para o ano de 2012 e desembolsos do BNDES para o período de 2004 a 2012, por município e unidades federativas da região Nordeste.

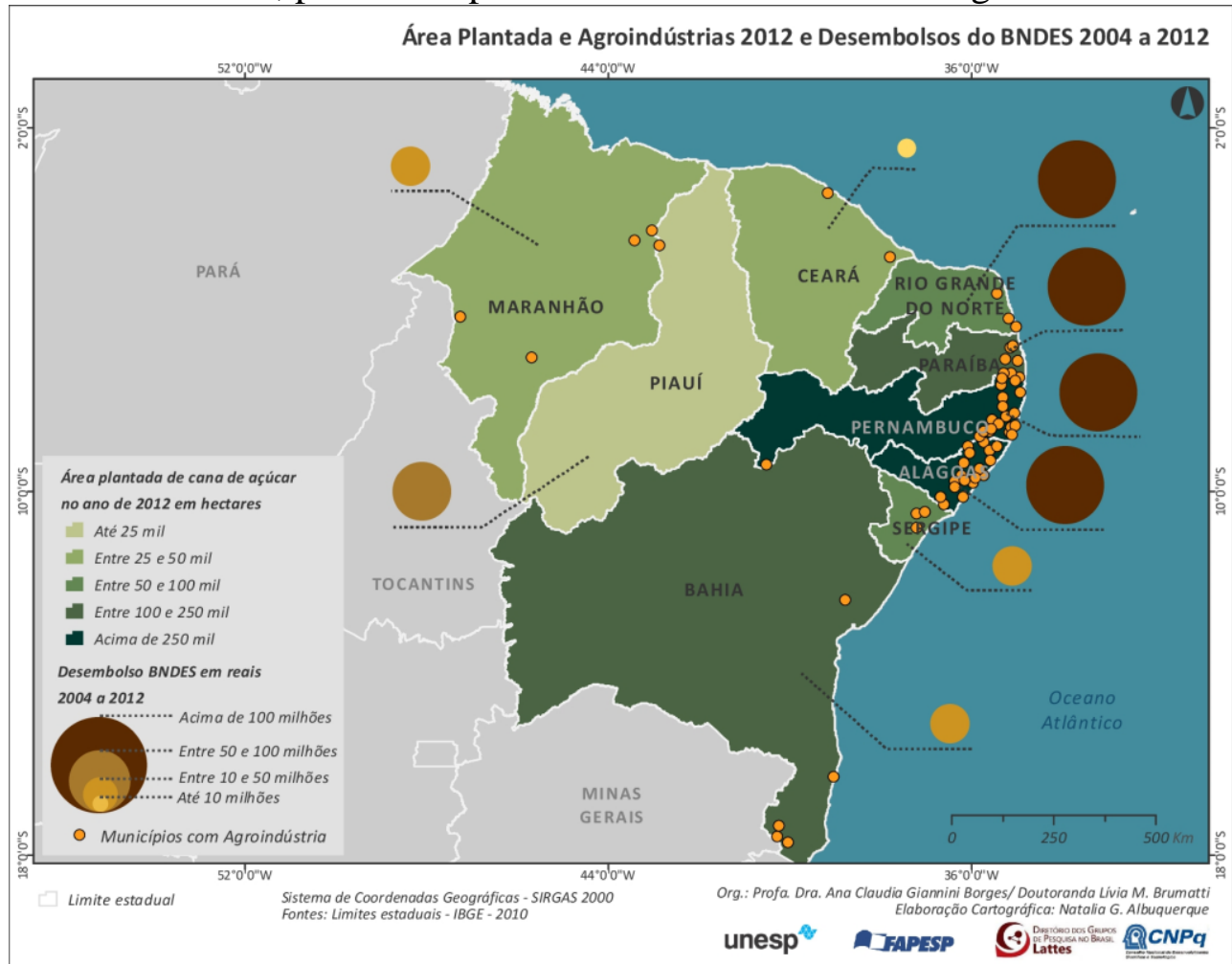

Fonte: Elaborada a partir de dados obtidos no BNDES nos anos de 2010 e 2013, mediante solicitação, MAPA (2012) e IBGE (2017).

Ainda nesse sentido, o município de Piancó, na Paraíba, apresenta pequena quantidade de área plantada (10 hectares), por período reduzido (2 anos), contudo recebe $\mathrm{R} \$$ 254.705 do BNDES. Situação similar ocorre nos municípios de Baixa Grande do Ribeiro no

\footnotetext{
${ }^{6}$ É importante destacar que algumas agroindústrias, das mesorregiões analisadas, deixaram de funcionar antes de 2012: uma no Leste Alagoano (2009); uma na Metropolitana de Fortaleza (2011); uma no Litoral Norte (2011); duas na Mata Meridional Pernambucana (2009); uma na Mata Setentrional Pernambucana (2009); uma na Vitória de Santo Antão (2010); duas em São Francisco Pernambucano (2011); e uma no Leste Sergipano (2011).
} (MAPA, 2009, 2010, 2011 e 2012) 
Piauí e de Santo Antônio, Currais Novos e Água Nova no Rio Grande do Norte, visto que recebem desembolsos de $\mathrm{R} \$ 4.410 .583$, $\mathrm{R} \$$ 58.833, $\mathrm{R} \$ 729.414$ e $\mathrm{R} \$$ 136.910, respectivamente. (BNDES, 2010 e 2013; MAPA, 2012).

Esses casos de inconsistência na captação de recursos para áreas sem característica produtiva canavieira geram um alerta para a necessidade de maior fiscalização do Banco frente aos desembolsos oferecidos, bem como pode ser um indicativo de comportamento inadequado dos demandantes de recursos.

É possível verificar que a principal mesorregião captadora de Alagoas é o Leste Alagoano, com participação de 98,94\% (R $\$ 364,45$ milhões) do recurso do estado, sendo que a mesma possui 24 agroindústrias sucroalcooleiras, de 2008 a 2012. É importante ressaltar, segundo Duarte et al. (2009), que a produção do setor no estado já é relevante desde o período de 1948/49, visto que Alagoas era o quarto maior produtor do setor, representando $10 \%$ da produção país. Assim, como esse estado, os autores também destacam Pernambuco, no mesmo período, e Rio Grande do Norte, Sergipe e Paraíba que passam a ter produção expressiva no período de 1978/79.

Em Alagoas, as maiores captações são nos seguintes municípios: Coruripe com 40,16\% dos recursos (3 agroindústrias), São Miguel dos Campos com 13,69\% (3 agroindústrias) e Maceió com 12,23\% (1 agroindústria). O volume total captado nesses municípios é de R $\$ 243,41$ milhões, o que representa 66,08\% do estado. Apenas os municípios de Barra de São Miguel e Cajueiro têm agroindústria sucroalcooleira e não recebem recursos do BNDES, pois os outros 16 municípios apresentam captação. Outros 23 municípios recebem recursos do BNDES e não possuem agroindústria sucroalcooleira.

Os desembolsos do BNDES para a Bahia são da ordem de $\mathrm{R} \$ 45,12$ milhões, no período de 2004 a 2012, sendo as mesorregiões com os maiores níveis de captação: o Vale São-Franciscano da Bahia $(61,27 \%)$ que possui uma agroindústria sucroalcooleira; a do Sul Baiano (18,03\%) com 4 agroindústrias em 2012; e a Centro-Sul Baiano (11,24\%) sem agroindústrias. Juntas somam R \$ 40,86 milhões, o que representam 90,54\% do estado.

Na mesma base do BNDES (2010 e 2013) e do MAPA (2012), tem-se que os municípios que recebem os maiores recursos são: Juazeiro com $\mathrm{R} \$ 27,6$ milhões $(61,27 \%)$ e Medeiros Neto com R\$3,06 milhões, ambos com uma unidade de agroindústria sucroalcooleira cada; e Jequié com R\$2,60 milhões, sem agroindústria. Os municípios de Amélia Rodrigues e Santa Cruz de Cabrália possuem agroindústrias e não recebem recursos do BNDES. Por outro lado, 28 municípios recebem desembolsos do BNDES e não tem 
agroindústria sucroalcooleira. Vale destacar, os municípios de Novo Horizonte, Jequié, Formosa do Rio Preto e Mucuri, pois captam R\$ 7,18 milhões no BNDES, o que representam $15,92 \%$ dos recursos recebidos pelo estado.

O Ceará recebe R\$ 6,58 milhões de recursos do BNDES, de 2004 a 2012. As mesorregiões de destaque são: Metropolitana de Fortaleza (51,15\%); Jaguaribe (20,06\%); e Sertões Cearenses $(15,30 \%)$. Vale ressaltar que as duas primeiras mesorregiões possuem agroindústrias sucroalcooleiras nos municípios de Aquiraz e Jaguaruana e são responsáveis por $12,77 \%$ ( $\mathrm{R} \$$ 839.856) e 19,20\% ( $\$$ \$ 1,26 milhões) das captações do estado, respectivamente. O município de Fortaleza é o principal destaque em captação $(38,39 \%)$ do estado, com o montante de R 2,53 milhões, e, também, está localizada na mesorregião Metropolitana de Fortaleza. Desses três municípios citados, Fortaleza é o único que não tem uma unidade de agroindústria. Paraipaba é outro município com agroindústria sucroalcooleira e com captação de 2,32\% ( $\mathrm{R} \$ 152.311)$ do total do estado. Vale ressaltar que 14 municípios captam recursos e não possuem agroindústria sucroalcooleira. Dos municípios que captam e possuem agroindústria, têm-se: Paraipaba com 8,36\%, Jaguaruana com 4,47\% e Aquiraz com $3,03 \%$ do total da área com cana-de-açúcar do estado.

O estado do Maranhão recebe R\$ 35,18 milhões, de 2004 a 2012, tendo os principais anos de captação: 2008 (R\$ 17,12 milhões) e 2011 (R\$ 9,52 milhões). É importante considerar que o estado passa a captar a partir do ano de 2007 e em todos os anos posteriores. As principais mesorregiões em captação são Sul Maranhense com 64,85\% (R \$ 22,81 milhões) e Leste Maranhense com 32,23\% (R\$ 11,03 milhões), com duas agroindústrias sucroalcooleiras cada. Nessas mesorregiões, os municípios de São Raimundo das Mangabeiras e Aldeias Altas possuem uma agroindústria cada e captam 63,45\% (R\$22,32 milhões) e 32,13\% (R \$ 11,30 milhões), respectivamente, dos desembolsos do estado. Dos municípios que recebem recursos, cinco não têm agroindústria e captam $3,71 \%$ ( $\$$ \$ 1,31 milhões) do montante do estado. Por outro lado, Coelho Neto possui uma agroindústria e não faz captação no BNDES, no período de análise. (BNDES, 2010 e 2013; MAPA, 2012).

O estado da Paraíba captou 9,84\% dos desembolsos para a região Nordeste, de 2004 a 2012, o que representa $\mathrm{R} \$ 111,14$ milhões de $\mathrm{R} \$ 1,13$ bilhões. Os desembolsos, desse estado, concentram-se quase integralmente na mesorregião da Mata Paraibana, que participa com 98,42\% (R \$ 109,39 milhões). Os municípios com maiores valores em captação possuem unidades agroindústrias sucroalcooleiras, são eles: Pedras de Fogo com 31,38\% (1 agroindústria); Mamanguape com 22,52\% (1 agroindústria); Santa Rita com 22,03\% (4 
agroindústrias); e Caaporã com 11,96\% (1 agroindústria). Juntas receberam 87,89\% (R\$ 97,69 milhões) do estado. Ressalta-se que, nesse estado, 17 municípios não possuem agroindústria sucroalcooleira e recebem recursos $\mathrm{R} \$ 9,02$ milhões de recursos, o que representam $8,12 \%$ do estado.

O estado de Pernambuco recebe 27,64\% (R \$ 312,36 milhões) dos R \$ 1,05 bilhão da região Nordeste, distribuídos nos anos de 2004 e 2012. A principal mesorregião em captação de recursos é a Mata Pernambucana com 70,98\% (R \$ 221,70 milhões) e a Metropolitana de Recife (R\$89, 33 milhões) que juntas correspondem a 99,57\%. É possível identificar 36 municípios recebedores de desembolsos, sendo os principais: Igarassu (22,53\%), Cortes (14,96\%), Lagoa do Itaenga (11,65\%) e Camutanga (10,02\%). Juntos esses municípios receberam 59,17\% (R\$ 184,83 milhões) do estado. Dos 36 municípios, três (Bom Jardim, Limoeiro e Santa Cruz da Baixa Verde) não têm agroindústria sucroalcooleira no município e na mesorregião e recebem o montante de R\$ 1.329.973. Por outro lado, há três municípios (Joaquim Nabuco, Vivência e Timbaúba) com agroindústrias e que não recebem desembolsos do BNDES.

Em BNDES (2010 e 2013), o estado do Piauí recebe, de 2004 a 2012, R\$ 55,38 milhões, o que representa 93\% das captações do estado no período de 2001 a 2012. Os desembolsos ocorrem para duas mesorregiões: a Centro-Norte Piauiense (92,04\%), que possui a única agroindústria sucroalcooleira do estado, e a Sudoeste Piauiense (7,96\%). O principal desembolso ocorre no município de União, onde está localizada a agroindústria MAPA (2012). Esse município recebe quase a integralidade do desembolso da mesorregião, que é de 91,59\% ( $\mathrm{R} \$ 50,72$ milhões). O restante foi captado por Campo Maior (0,44\%) e Baixa Grande do Ribeiro (7,96\%). Vale destacar que a área para a produção de cana-de-açúcar é inexistente no primeiro município e de no máximo 7 ha para o segundo. (IBGE, 2017).

Ainda, verifica-se que a mesorregião de Leste Potiguar, no Rio Grande do Norte, capta 99,44\% dos recursos recebidos pelo estado do Rio Grande do Norte e sediava as quatro únicas agroindústrias potiguares. Sendo que o município de Baia Formosa apresenta uma agroindústria e tem participação de 93,77\% das captações do estado. O município de CearáMirim possui duas agroindústrias e não recebe desembolsos. Os recursos são recebidos em nove municípios, dos quais apenas dois apresentam agroindústrias (Baia Formosa e Arês). Os outros sete municípios recebem 2,22\% ( $\$$ \$ 3,69) do montante do estado, sendo que Santo Antônio e Currais Novos não tem área plantada de cana-de-açúcar no período de 2004 a 2012 
e Água Nova apenas 4 hectares nos anos de 2011 e 2012. Esses três municípios recebem R\$ 925.157.

O estado de Sergipe capta R \$29,48 milhões, de 2004 a 2012, sendo que 82,21\% para a mesorregião do Leste Sergipano e a 17,79\% para Agreste Sergipano. A primeira possui 3 agroindústrias e a segunda uma agroindústria. Os municípios com as maiores captações são Capela com 53,94\% (2 agroindústrias), Laranjeiras com 21,29\% (1 agroindústria) e Nossa Senhora das Dores 16,62\% (1 agroindústria), que juntas somam R \$ 27,08 milhões. Logo, dos 13 municípios que recebem recursos do BNDES, 10 não possuem agroindústrias sucroalcooleiras em 2012 e apenas Aquidabã não possui também área plantada de cana-deaçúcar. No entanto, desses municípios, deve-se destacar que Japoatã, até 2011, possuía uma unidade ativa no município (MAPA, 2011).

A partir desses dados, pode-se constatar que os maiores desembolsos (acima de R $\$$ 100 milhões) estão no Leste Alagoano, Mata Paraibana e Leste Potiguar, mesorregiões que abrangem inclusive o litoral, e na Mata Pernambucana mesorregião próxima ao litoral que juntas recebem R\$ 861 milhões, o que representa 76,19\% da região Nordeste. Além disso, são as mesorregiões que a área de cana-de-açúcar tem a maior participação na área territorial. Essas mesorregiões também possuem o maior número de agroindústrias sucroalcooleiras, sendo 24, 9, 17 e 3 respectivamente (FIGURA 2).

Nessas mesorregiões, observa-se que a área plantada com cana-de-açúcar tem participação relevante na área plantada total, com lavouras temporárias e permanentes, para os anos de 2004 e 2012 (TABELA 6). Nessas mesorregiões, exceto para a mesorregião Leste Potiguar, a cana-de-açúcar utiliza mais de $70 \%$ da área plantada total.

Verifica-se a predominância da lavoura da cana-de-açúcar frente as demais lavouras, inclusive aquelas ligadas à alimentação básica do brasileiro (arroz e feijão), ou seja, estas perdem espaço para as culturas que não fazem parte da base da alimentação, mas sim de fatores energéticos ou de commodities destinadas à exportação (DELGADO, 2010; OLIVEIRA, 2016). Nesse debate, Souza (2013) menciona em seu estudo sobre o processo de expansão do 'setor sucroenergético' no estado de São Paulo e que esta expansão fortalece o mercado de terras ('terra de negócio') em detrimento da 'terra de trabalho', sobrevalorizando os preços das terras e aumentando a concentração fundiária. Consequentemente, há um aumento nas diferenças sociais, uma vez que esse novo cenário afeta diretamente a agricultura familiar e o pequeno produtor. Além de afetar também as condições de preço do alimento básico para o consumidor final. 
Tabela 6. Área plantada das principais lavouras (temporárias e permanentes) e participação na área total plantada (\%), no ano de 2004 e 2012.

\begin{tabular}{|c|c|c|c|c|c|}
\hline & \multirow{2}{*}{$\begin{array}{c}\text { Produto das lavouras } \\
\text { temporárias e permanentes }\end{array}$} & \multicolumn{2}{|c|}{ Área plantada (Hectares) } & \multicolumn{2}{|c|}{ Participação no total (\%) } \\
\hline & & 2004 & 2012 & 2004 & 2012 \\
\hline \multirow{7}{*}{ Leste Alagoano } & Cana-de-açúcar & 410.515 & 420.219 & 90,91 & 94,78 \\
\hline & Coco da Baía & 13.072 & 5.955 & 2,89 & 1,34 \\
\hline & Laranja & 3.866 & 4.273 & 0,86 & 0,96 \\
\hline & Arroz (em casca) & 2.821 & 2.904 & 0,62 & 0,66 \\
\hline & Banana (cacho) & 3.809 & 2.746 & 0,84 & 0,62 \\
\hline & Mandioca & 4.541 & 2.484 & 1,01 & 0,56 \\
\hline & Total & 451.586 & 443.340 & 100 & 100 \\
\hline \multirow{7}{*}{ Mata Paraibana } & Cana-de-açúcar & 110.942 & 119.290 & 74,38 & 80,92 \\
\hline & Mandioca & 8.200 & 7.450 & 5,50 & 5,05 \\
\hline & Abacaxi & 6.945 & 7.154 & 4,66 & 4,85 \\
\hline & Coco da Baía & 9.520 & 7.043 & 6,38 & 4,78 \\
\hline & Batata Doce & 2.327 & 1.058 & 1,56 & 0,72 \\
\hline & Feijão (em grão) & 3.163 & 1.010 & 2,12 & 0,69 \\
\hline & Total & 149.156 & 147.410 & 100 & 100 \\
\hline \multirow{7}{*}{ Mata Pernambucana } & Cana-de-açúcar & 268.466 & 224.242 & 88,68 & 89,09 \\
\hline & Banana (cacho) & 15.683 & 15.482 & 5,18 & 6,15 \\
\hline & Coco da Baía & 6.559 & 3.926 & 2,17 & 1,56 \\
\hline & Mandioca & 6.616 & 2.617 & 2,19 & 1,04 \\
\hline & Milho (em grão) & 1.228 & 1.670 & 0,41 & 0,66 \\
\hline & Feijão (em grão) & 1.728 & 1.456 & 0,57 & 0,58 \\
\hline & Total & 302.721 & 251.692 & 100 & 100 \\
\hline \multirow{7}{*}{ Leste Potiguar } & Cana-de-açúcar & 48.359 & 63.860 & 31,26 & 52,28 \\
\hline & Castanha de caju & 28.901 & 23.087 & 18,68 & 18,90 \\
\hline & Coco da Baía & 28.280 & 18.965 & 18,28 & 15,53 \\
\hline & Mandioca & 17.277 & 6.955 & 11,17 & 5,69 \\
\hline & Abacaxi & 3.477 & 4.283 & 2,25 & 3,51 \\
\hline & Banana (cacho) & 2.740 & 1.756 & 1,77 & 1,44 \\
\hline & Total & 154.676 & 122.146 & 100 & 100 \\
\hline
\end{tabular}

Fonte: Elaborada a partir de IBGE (2017).

De fato, quando se observa as mesorregiões que, no período de 204 a 2012, recebem as maiores quantidades desembolsos do BNDES na região Nordeste (TABELA 7), pode-se verificar uma redução da diversidade produtiva com tendência à homogeneidade territorial, exceto no caso da mesorregião da Mata Pernambucana que já apresentava, em 2004, uma diversidade reduzida e manteve esta situação.

Tabela 7. Índice de Theil nas mesorregiões com desembolsos acima de R $\$ 100$ milhões, para os anos de 2004 a 2012.

\begin{tabular}{l|cllllllll}
\cline { 2 - 9 } & 2004 & 2005 & 2006 & 2007 & 2008 & 2009 & 2010 & 2011 & 2012 \\
\hline Leste Alagoano & 0,5006 & 0,5147 & 0,4965 & 0,4860 & 0,4842 & 0,4591 & 0,4258 & 0,3977 & 0,3141 \\
Mata Paraibana & 1,1245 & 1,2146 & 1,1390 & 1,1471 & 1,1351 & 1,0952 & 0,9583 & 0,9972 & 0,8579 \\
Mata Pernambucana & 0,5360 & 0,5138 & 0,4947 & 0,4781 & 0,4946 & 0,5411 & 0,6128 & 0,6392 & 0,5162 \\
Leste Potiguar & 1,9651 & 1,8969 & 1,9077 & 1,7747 & 1,7488 & 1,7132 & 1,6408 & 1,7344 & 1,4254 \\
\hline
\end{tabular}

Fonte: Elaborada pelas autoras a partir de IBGE (2017). 
Esse índice corrobora o observado na Tabela 6, onde se identifica a predominância da lavoura da cana-de-açúcar frente a área total plantada, bem como na participação na área territorial.

\section{CONSIDERAÇÕES FINAIS}

É possível constatar que apesar da redução da participação do Estado principalmente no período pós 1990, suas instituições financeiras, especificamente o BNDES, permanecem com grande importância. O BNDES desembolsa um total de $\mathrm{R} \$ 63,63$ bilhões para 26 unidades federativas, no período de 2001 a 2012, dos quais R \$ 1,59 bilhões são destinados para a região Nordeste.

Os estados de Alagoas (R 679 milhões) e Pernambuco (R \$ 380 milhões) são os principais estados em captação de recursos do BNDES e possuem as maiores áreas plantadas de cana-de-açúcar e o maior número de agroindústrias. As outras unidades federativas de destaque são: Rio Grande do Norte, Paraíba e Piauí, com R\$ 209 milhões, R\$ 149 milhões e $\mathrm{R} \$ 59$ milhões respectivamente.

As principais finalidades de desembolsos do BNDES, de 2001 a 2008, no Nordeste são: financiamento de compra e expansão, que somam $88,81 \%$ dos recursos. As principais unidades federativas captadoras são, para financiamento de compra e expansão, Alagoas e Pernambuco, seguido por Paraíba, Rio Grande do Norte e Piauí. Para os desembolsos de 2009 a 2012, as principais finalidades são a fabricação de açúcar bruto, cultivo de cana-de-açúcar e geração de energia elétrica a partir da cogeração de cana-de-açúcar. Nessa última, destaca-se Rio Grande do Norte que capta a integralidade dos recursos destinados a esta finalidade. Alagoas recebe 53\% dos recursos destinados para a fabricação de açúcar bruto e 49,6\% para o cultivo de cana-de-açúcar.

$\mathrm{Na}$ análise por mesorregião, é possível observar a ocorrência de desembolsos em municípios sem produção canavieira efetiva e agroindústria sucroalcooleira o que ressalta $\mathrm{o}$ problema de uso inadequado dos recursos captados no BNDES, bem como uma possível deficiência, do Banco, no sistema de controle de captação desses recursos. É importante ressaltar que essa consideração está sustentada em dados secundários disponibilizados pelo IBGE e MAPA, o que evidencia a necessidade de novos estudos para testar essas considerações, por meio de pesquisas que se sustentem em coletas de dados primários nas localidades. 
No entanto, observa-se que os desembolsos do BNDES são atraídos pela dinamicidade de determinadas regiões, bem como podem ser o dinamizador delas, uma vez que os recursos contribuem para a concentração e consolidação do setor em algumas regiões, como é o caso da costa leste do Nordeste. Essa tendência resulta no aumento da participação da área cultivada de cana-de-açúcar frente a de outras culturas, resultando, portanto, na perda da diversidade produtiva e na homogeneização da paisagem.

\section{REFERÊNCIAS}

BAER, W.; NAZMI, N. O sistema Bancário: privatização e reestruturação. In: BAER, W. A economia brasileira. São Paulo: Nobel, 2002. p. 318-339.

BACCARIN, J.G. A constituição da nova regulamentação sucroalcooleira. Brasília UNB: Editora UNESP, 2005. 243 p.

BARROS, G.C.; MOARES, M.A.F.D. A desregulamentação do setor sucroalcooleiro. Revista de Economia Política. São Paulo, v.22, no. 2 (86), p. 153-176, abr.-jun. 2002.

BCB. BANCO CENTRAL DO BRASIL. Departamento de Estatística. Spread Médio das operações de crédito - Total e Pessoa Jurídica. 2018. Disponível em: https://www3.bcb.gov.br/sgspub/localizarseries/localizarSeries.do?method=prepararTelaLocaliza rSeries. Acesso em:04 set. 2017.

BCB. BANCO CENTRAL DO BRASIL. Juros e Spread Bancário - Informações até junho de 2016. 2016. Disponível em: https://www.bcb.gov.br/content/cidadaniafinanceira/Doc uments/publicacoes/serie_pmf/FAQ\%2001-Juros\%20e\%20Spr ead\%20Banc\%C3\%A1rio.pdf. Acesso em: 02 abr. 2019.

BM\&F. Bolsa de mercadorias e futuro. Produtos e serviços - Commodities. Disponível em: http://www.b3.com.br/pt_br/produtos-e-servicos/negociacao/commodities/. Acesso em: 25 mar. 2019.

BORGES, A. C. G. Desembolsos do BNDES para o setor sucroenergético no estado de Goiás. Campo-Território: revista da geografia agrária, Uberlândia (MG), v.10, n. 20, p. 88-113, 2015 .

BORGES, A. C. G.; COSTA, V. M. H M. Fusões e aquisições no setor sucroalcooleiro pós desregulamentação. In: Encontro Nacional de Engenharia de Produção - A Engenharia de Produção e o Desenvolvimento Sustentável: Integrando Tecnologia e Gestão (ENEGEP), XXIX, 2009, Salvador. Anais [...]. Salvador: ENEGEP, 2009. p. 1-14. 
CARNEIRO, R. Desenvolvimento em crise: A economia brasileira no último século XX. São Paulo: Editora Unesp, IE -Unicamp, 2002. 423 p.

CARVALHO, C. E.; TEPASSÊ, A. C. O BNB como banco de desenvolvimento e banco de crédito agrícola: desempenho, mudanças, desafios. Revista de planejamento e políticas públicas, Brasília: IPEA, n. 34, p. 87-130, jan./jun. 2010.

CONAB. Companhia Nacional de Abastecimento. Acompanhamento da safra brasileira de cana-de-açúcar - safra 2016/2017 - Primeiro levantamento. Brasília: Conab, v. 3, abr. 2016. 66 p. Disponível em: https://www.conab.gov.br/info-agro/safras/cana/boletim-da-safra-decana-de-acucar?start=10. Acesso em: 01 abr. 2019.

CONAB. Companhia Nacional de Abastecimento. Perfil do setor do açúcar e do álcool no Brasil - safra 2011/2012. Brasília: Conab, v. 5, 2013. 88 p. Disponível em: https://www.conab.gov.br/info-agro/safras/cana/perfil-do-setor-sucroalcooleiro/item/do wnload/23296_e8994bb0d8652261a47cf54ac4332120. Acesso em: 01 abr. 2019.

DELGADO, G. C. Especialização primária como limite ao desenvolvimento. Desenvolvimento em Debate, Rio de Janeiro, v.1, n.2, p.111-125, jan.-abr. e mai.-ago. 2010.

DUARTE, L. M. G.; VAlARIÉ, P.; VIANNA, J. N. S.; WEHRMANN, M. E. S. F. A territorialização do setor sucroalcooleiro no Brasil - de 1948/49 a 2006/2007. In: Congresso Lusófono de Ambiente e Energia, 1², 2009, Cascais - Portugal. Anais [...]. Cascais, 2009. 1$20 \mathrm{p}$.

IBGE. Instituto Brasileiro de Geografia e Estatística. Cidade e Estados do Brasil. 2017. Disponível em: www.cidades.ibge.gov.br. Acesso em: 18 jan. de 2018.

IBGE. Instituto Brasileiro de Geografia e Estatística. Banco de Dados Agregados - SIDRA. 2017. Disponível em: http://www.sidra.ibge.gov.br/. Acesso em: 25 mai. de 2017.

IBGE. Instituto Brasileiro de Geografia e Estatística. Divisão Regional do Brasil em mesorregiões e microrregiões geográficas. Rio de Janeiro: IBGE, v.1, 1990. Disponível em: https://biblioteca.ibge.gov.br/visualizacao/livros/liv2269_1.pdf. Acesso em: 27 mar. 2019.

JORNALCANA. Anuário da cana 2011: safra 2010/2011. Ribeirão Preto: Procana, 2011.

MAPA. Secretaria de Política Agrícola. Departamento da cana-de-açúcar e agroenergia. Relação das unidades produtoras cadastradas do departamento de cana-de-açúcar e 
agroenergia, vários anos (2008 a 2012). Disponível em: http://www.agricultura.gov.br/ vegetal/culturas/cana-de-acucar. Acesso em: 18 out. 2013.

MILANEZ, A. Y.; BARROS, N. R.; FAVERET FILHO, P. S. C. O perfil do apoio do BNDES ao setor sucroalcooleiro. BNDES Setorial, Rio de Janeiro, n. 28, p. [3]-36, set. 2008. Disponível em: http://www.bndes.gov.br/SiteBNDES/export/sites/default/bndes_pt/Galerias/ Arquivos/conhecimento/bnset/set2801.pdf. Acesso em: 10 ago. 2009.

OLIVEIRA, A. U. A mundialização da Agricultura Brasileira. São Paulo: Iandé Editorial, 2016. 545 p.

SOUZA, J. G. A produção brasileira de etanol e seus efeitos sobre o valor da terra, sobre a concentração fundiária e sobre a homogeneização da paisagem. Diversitates, Niterói (RJ), v. 5, p. 29-58, 2013.

SOUZA, J.G. Questão de Método: a homogeneização do território rural paulista. Jaboticabal: FCT-Unesp, 2008. (Tese de Livre Docência).

SOUZA, J. G.; CABERO DIEGUES, V. Por uma desglobalização da produção alimentar: commoditização da agricultura e diversidade produtiva - uma análise de Espanha. GEOgraphia - UFF, Niterói (RJ), v. 14, p. 63 - 81, 2012. 172 p.

STUDART, R. O financiamento do desenvolvimento. In: GIAMBIASI, F.; VILLELA, A.; CASTRO, L. B. de; HERMANN, J. (Org.). Economia Brasileira Contemporânea. Rio de Janeiro: Elsevier, 2005. p. 335-354.

TORRES FILHO, E. T.; COSTA, F. N. BNDES e o financiamento do desenvolvimento. Economia e Sociedade, Campinas (SP), v. 21, número especial, p. 975-1009, dez. 2012.

UNICA. União da Indústria de Cana-de-açúcar. Moagem de Cana-de-açúcar. Disponível em: http://www.unicadata.com.br/historico-de-producao-e-moagem.php?idMn=31\&tipo Historico=2. Acesso em: 3 mai. 2017.

VIAN, C.E.F. Agroindústria canavieira: estratégias competitivas e modernização. Campinas (SP): Editora Átomo, 2003. 216 p.

VIAN, C.E.F.; BELIK, W. Os desafios para a reestruturação do complexo agroindustrial canavieiro do Centro-Sul. Economia, Niterói (RJ), v. 4, n. 1, p. 153-194, jan./jun. 2003. 